Jambura Journal of Community Empowerment (JJCE)

Volume (2) Nomor (2), (Desember) (2021), Halaman (83-93)

ISSN (e): 2721-0480

DOI Prefix: https://doi.org/10.37411/jjce.v2i2.598

\title{
Pengaruh Interaktif Kelas Terhadap Hasil Belajar Pada Program Paket B Mata Pelajaran Bahasa Indonesia Di Sanggar Kegiatan Belajar Kota Gorontalo
}

\author{
Fajri Lalisu', Abdul Rahmat ${ }^{2}$ \\ Pendidikan Luar Sekolah Fakultas Ilmu Pendidikan Universitas Negeri Gorontalo \\ flalisu@gmail.com ${ }^{1}$, abdulrahmat@ung.ac.id ${ }^{2}$
}

Received: 05 Februari 2021; Revised: 31 Desember 2021; Accepted: 31 Desember 2021

\begin{abstract}
This study aims to test and prove whether there is an influence between the interactive classroom approach on improving the learning outcomes of learning residents in the Gorontalo City Learning Activity Center. The research method used in this study is a quantitative method. This research is an associative research type with a causal relationship where there are independent and dependent variables. Data analysis techniques through normality test, validity test, sampling technique and test requirements data analysis using simple regression analysis. The results of the regression analysis test show that the significant value of $t$ arithmetic is smaller than alpha and the value of the $\mathrm{t}$ arithmetic test is greater than $\mathrm{t}$ table so that $\mathrm{H} 0$ is rejected and $\mathrm{H} 1$ is accepted or interactive tutor has a positive and significant effect on learning outcomes. For class interactive effect (X) is $0.000<0.05$ and $t$ Count 5.075>t table 1.701, . Thus the $t$ test hypothesis for Ha (class interactive variable) has an effect. Thus the first hypothesis (Ha) can be proven or accepted.
\end{abstract}

Keywords: Class interactive, learning outcomes, Programe Package B.

\begin{abstract}
ABSTRAK
Penelitian ini bertujuan untuk menguji dan membuktikan apakah terdapat pengaruh antara pendekatan interaktif kelas terahadap peningkatan hasil pembelajaran warga belajar di Sanggar Kegiatan belajar Kota Gorontalo. Metode penelitian yang digunakan dalam penelitian ini adalah metode kuantitatif. Penelitian ini merupakan jenis penelitian asosiatif dengan hubungan kausal dimana terdapat variabel bebas dan terikat. Teknik analisis data melalui uji normalitas, uji validitas, teknik sampling dan uji persyarata analisis data menggunakan analisis regresi sederhana. Hasil uji analisis regresi yang menunjukan bahwa nilai signifikan t hitung lebih kecil dari alpha dan nilai uji t hitung lebih besar dari t tabel sehingganya $\mathrm{H} 0$ ditolak dan $\mathrm{H} 1$ diterima atau interaktif tutor memiliki pengaruh positif dan signifikan terhadap hasil pembelajaran. Untuk pengaruh interaktif kelas $(\mathrm{X})$ adalah sebesar $0,000<0.05$ dan $\mathrm{t}_{\text {Hitung } 5,075>\mathrm{t}}$ tabel 1,701, .Dengan demikian hipotesis uji t untuk $\mathrm{H}_{\mathrm{a}}$ (variabe linteraktif kelas) berpengaruh. Dengan demikian hipotesis pertama $\left(\mathrm{H}_{\mathrm{a}}\right)$ dapat dibuktikan atau diterima.
\end{abstract}

Kata Kunci: Interaktif kelas, hasil belajar, Program Paket B.

(C)2021 by Fajri Lalisu, Abdul Rahmat Under the license CC BY-SA 4.0

\section{PENDAHULUAN}

Pendidikan merupakan suatu kegitan sadar manusia dalam meningkatkan kualitas hidup baik itu pendidikan formal dan nonformal. Dari tignkat sadar itulah di katakana bahwa pendidikan memiliki tujuan dan terstruktur, berkesinambungan 
serta tersistematika dalam satu kurikulum. (Mulyasa 2004). tentang pentingnya pengembangan system pendidikan yang berkualitas perlu lebih ditekankan, karena berbagai indikator menunjukan bahwa pendidikan yang ada belum mampu menghasilkan sumber daya sesuai dengan perkembanagan masyarakat dan kebutuhan pembangunan.

Pendidikan saat ini merupakan salah satu sarana untuk melancarkan komunikasi antara pendidik dengan peserta didik yang bertujuan untuk menyampaikan sebuah informasi. Pendidikan berkembang pesat seiring dengan kemajuan zaman modern (Arif, 2020).

Dalam Sistem Pendidikan Nasional dikenal jalur pendidikan di luar pendidikan formal yang dapat dilaksanakan secara terstruktur dan berjenjang yaitu pendidikan non-formal atau Pendidikan Luar Sekolah. Setiap kegiatan pendidikan yang terorganisir dan diselenggarakan di luar sistem formal baik tersendiri maupun merupakan bagian dari suatu kegiatan yang luas, yang dimaksudkan untuk memberikan layanan kepada sasaran didik tertentu dalam rangka mencapai tujuan-tujuan belajar adalah Pendidikan Luar Sekolah (Prasetyo, 2017). Pendidikan yang dimaksud meliputi pendidikan kecakapan hidup, pendidikan anak usia dini, pendidikan kepemudaan, pendidikan pemberdayaan perempuan, pendidikan keaksaraan, pendidikan keterampilan dan pelatihan kerja, pendidikan kesetaraan, serta pendidikan lain yang ditujukan untuk mengembangkan kemampuan peserta didik. (UU Sisdiknas 2003 Pasal 26 ayat (3). Kesemuanya beraktivitas dalam satuan pendidikan nonformal yang terdiri atas lembaga kursus, lembaga pelatihan, kelompok belajar, pusat kegiatan belajar masyarakat dan majelis taklim serta satuan pendidikan yang sejenis (UU Sisdiknas 2003 Pasal 26 ayat (4). Sanggar Kegiatan Belajar adalah salah satu unit pelaksana teknis yang dimaksud. Seperti halnya unit pelaksana teknis yang lain, Sanggar Kegiatan Belajar melaksanakan beberapa kegiatan teknis cakupan Pendidikan Luar Sekolah seperti program Kejar Paket B, Paket C, kursus-kursus keterampilan, kelompok belajar usaha, kelompok belajar olahraga dan lain sebagainya.

Untuk mengaktifkan interaksi baik warga belajar dengan pamong belajar ataupun dengan sesama warga belajar sendiri, pamong juga sudah terbiasa dengan 
memberi waktu kepada warga belajar untuk menanyakan hal yang belum jelas atau belum dimengerti dan yang jarang ditemukan pada setiap proses pembelajaran adalah analisis pengalaman. Tidak bisa dipungkiri bahwa warga belajar yang ada, bukan anak-anak lagi, yang hanya bisa menerima apa yang diberikan oleh si pengajar. Tapi warga belajar adalah orang dewasa yang memiliki pengalaman yang bukan tidak mungkin bisa melebihi pengalaman pamong belajarnya. Analisis pengalaman yang sesuai dengan tema materi yang diusung pada saat pembelajaran akan sangat berguna bagi warga belajar. Di samping itu, interaksi aktif yang dominan dari warga belajar sulit ditemukan jika pamong belajar masih menyamakan warga belajarnya dengan anakanak. Padahal sebenarnya pamong belajar tidak perlu repot memberikan pengetahuannya kepada warga belajar jika sudah menganggap warga belajar sebagai orang dewasa yang sudah bisa mengarahkan dirinya sendiri walaupun saat itu materi yang dihadapi adalah yang paling sulit sekalipun. Jadi pamong belajar mengandalkan keaktifan dari warga belajarnya dalam berinteraksi pada proses pembelajaran. Aktivitas yang ada baru menggambarkan sebagian dari peran pamong belajar dalam proses pembelajaran pada program Paket B (Prasetyo, 2017).

Arsyad (2017) Belajar adalah suatu proses yang kompleks yang terjadi pada diri setiap orang sepanjang hidupnya. Proses belajar itu terjadi karean adanya interaksi antara seseorang dengan lingkungannya. Oleh karena itu belajar dapat terjadi kapan saja dan dimana saja. Salah satu pertanda bahwa seseorang itu telah belajar adalah adanya perubahan tingkah laku pada diri orang itu yang mungkin disebabkan oleh terjadinya perubahan pada tingkat pengetahuan, keterampilan, atau sikapnya.

Penguasaan materi merupakan salah satu hal penting bagi siswa untuk perlu diciptakan kondisi pembelajaran yang efektif dan inovatif dimana terjadi interaksi antara pamong dan warga belajar sehingga dapat menciptakan situasi dan kondosi lingkungan belajar yang aktif dan menyenangkan (Setyaningsih, 2020)

terlepas pada pembahasan diatas, peneliti berusaha untuk memaparkan beberapa kesenjangan yang nampak berdasarkan pengamatan dalam praktek maggang saya di lembaga pendidikan non formal, khususnya di Sanggar Kegiatan 
belajar Kota Gorontalo. Sanggar Kegiatan belajar kota Gorontalo merupakan suatu lembaga pendidikan yang diselengarakan diluar sistem pendidikan formal. Sanggar Kegiatan belajar kota Gorontalo memiliki berbagai macam program non formal salah satunya adalah program paket B yang saat ini menjadi obyek penelitian yang dilakukan peneliti.

Sesuai data yang diperoleh dari pengelola Sanggar Kegiatan belajar kota Gorontalo pada tahun ajaran 2018-2019 peneliti mendapatkan beberapa data melalui obeservasi pada pengambilan data awal bahwa jumlah warga belajar paket B yang ada di Sanggar Kegiatan belajar kota Gorontalo yakni 30 orang warga belajar. Dengan berbagai data yang di peroleh oleh peneliti di Sanggar Kegiatan belajar kota Gorontalo khususnya warga belajar paket B, peneliti mendapatkan tingkat partisipasi warga belajar paket B di Sanggar Kegiatan belajar kota Gorontalo dalam proses pembelajaran masih memiliki kekurangan dengan berbagai faktor serta hal-hal yang terjadi pada saat awal proses pembelajaran, saat itu pamong memberikan materi ada beberapa warga belajar yang kurang memperhatikan materi yang disampaikan pamong, ketika diskusi mengenai materi yang disajikan warga belajar masih ada saja warga belajar yang masih asik bermain dengan teman-teman, selain itu pada saat proses pembelajaran berlangsung ketika pamong menggunakan media bantu dalam pemebelajaran $(L C D)$, ada beberapa warga belajar kurang memperhatikan malah lebih asik melihat (Handphone) mereka. Hal ini dikarenakan penggunaan kata yang kurang di pahami dan kurannya perhatian dari pamong dalam membangun interaksi dalam kelas sehinnga apa yang di sampaikan baik secara lisan maupun alat bantu berupa media kurang dimengerti oleh warga belajar, dan juga karena warga belajar lebih memilih asik sendiri dengan kesibukan mereka di bandingkan memerhatikan pelajaran yang sedang berlangsung. Dengan demikian jika hal ini dibiarkan berlartu-larut tanpa adanya penanganannya maka akan secara langsung mempengaruhi proses pembelajaran bahkan dapat mempengaruhi hasil belajar warga belajar di Sanggar Kegiatan belajar kota Gorontalo kususnya pada Program paket B. 


\section{METODE}

Penelitian ini dilaksanakan di Sanggar Kegiatan belajar Kota Gorontalo. Adapun yang menjadi sasaran dalam penelitian ini adalah pamong di Sanggar Kegiatan belajar Kota Gorontalo. Penelitian ini merujuk pada Pengaruh Pendekatan Interaktif kelas Dalam Meningkatkan Hasil Pembelajaran Pada Paket B Mata Pelajaran Bahasa Indonesia di Sanggar Kegiatan belajar Kota Gorontalo adalah lokasi yang tepat karena merupakan salah satu Sanggar Kegiatan belajar Kota Gorontalo yang dapat mewakili criteria dalam penelitian ini. Selain itu, lokasi penelitian mudah untuk dijangkau sehingga dapat mengefisienkan waktu. Tenaga dan biaya dalam pengumpulan data mengenai indicator penelaitian.

\section{Uji Normalitas Data}

Teknik analisis data yang pertama kali dilakukan adalah uji normalitas data. Uji normalitas data dilakukan untuk mengetahui apakah data yang dihasilkan apakah berdistribusi normal atau tidak. Untuk uji normslitas digunakan uji normalitas Kolmogorov - Smirnov dengan taraf signifikansi $\alpha=$ 0,05. Uji ini dilakukan dengan bantuan program SPSS. Hipotesis statistik yang digunakan pada uji ini adalah sebagai berikut:

Ho: data yang diuji berdsitribusi normal

$\mathrm{H}_{1}$ : data yang di uji tidak berdistribusi normal.

\section{Uji Validitas}

Ridwan (2007) menjelaskan bahwa validitas adalah suatu yang menunjukkan tingkat keandalan atau keaslian suatu alat ukur. Untuk menguji validitas alat ukur, terlebih dahulu dicari harga korelasi antar bagian-bagian dari alat ukur secara keseluruhan dengan cara mengkorelasikan setiap butir alat ukur dengan skor total yang merupakan jumlah setiap skor butir. Untuk menghitung validitas alat ukur digunakan rumus Person Product Momen yaitu sebagai berikut:

$$
\text { rhitung }=\frac{n(\Sigma X i Y i)-(\Sigma X i) \cdot(\Sigma Y i)}{\sqrt{\{n \cdot \Sigma X 1-(\Sigma X i)\}} \cdot\{n \cdot \Sigma Y i 2-(\Sigma Y i) 2\}}
$$

Seluruh waraga belajar di Sanggar Kegiatan belajar Kota Gorontalo berjumlah 30 warga belajar. Setelah dilakukan analisis regresi menggunakan 
program SPSS, maka selanjutnya analsis menggunaka rumus persamaan regresi sederhana. Adapun rumus yang digunakan adalah sebagai berikut:

$$
\mathrm{Y}=\mathrm{a}+\mathrm{bX}
$$

Keterangan:

$\mathrm{Y}=$ Variabel dependen yang diprediksi

$\mathrm{a}=$ Konstanta (apabila nilai $\mathrm{x}$ sebesar 0 , maka Y akan sebesar a atau konstanta)

$\mathrm{b}=$ Koefisien regresi (nilai peningkatan atau penurunan)

$\mathrm{X}=$ Variabel independen .

\section{HASIL DAN PEMBAHASAN}

\section{Hasil}

Berdasarkan analisis data menunjukkan bahwa hasil penelitian ini ditunjukkan melalui tabel sebagai berikut:

Table 1. Uji Normalitas

One-Sample Kolmogorov-Smirnov Test

\begin{tabular}{llll}
\hline & & INTERAKTIF & HASIL \\
& & KELAS & BELAJAR \\
\hline Normal Parameters & & 30 & 30 \\
& & 62,2667 & 64,3000 \\
Most Extreme Differences & Mean & 7,32936 & 6,64442 \\
& Std. Deviation &, 145 &, 109 \\
& Absolute &, 083 &, 072 \\
& Positive &,- 145 &,- 109 \\
Kolmogorov-Smirnov Z & Negative &, 796 &, 595 \\
Asymp. Sig. (2-tailed) & &, 550 &, 871 \\
\hline
\end{tabular}

a. Test distribution is Normal.

b. Calculated from data.

Berdasarkan hasil olahan spss 19 yang terlihat pada tabel 4.6 uji normalitas data di atas, diketahui banyaknya sampel 30 warga belajar, hasil olahan diperoleh nilai K-S variabel interaktif kelas sebesar 0,796 dan variabel hasil belajar sebesar 0,595. Masing-masing variabel memperoleh nilai sig 2 tailed sebesar 0,550 pada variabel interaktif kelas dan varaibel hasil belajar sebesar 0,871 terlihat bahwa kedua variabel memiliki nilai sig 2 tailed $>0,05$ artinya data kedua variabel pada pengujian ini telah terdistribusi normal. Data yang normal juga dapat dilihat dari gambar p-p plot berikut ini: 


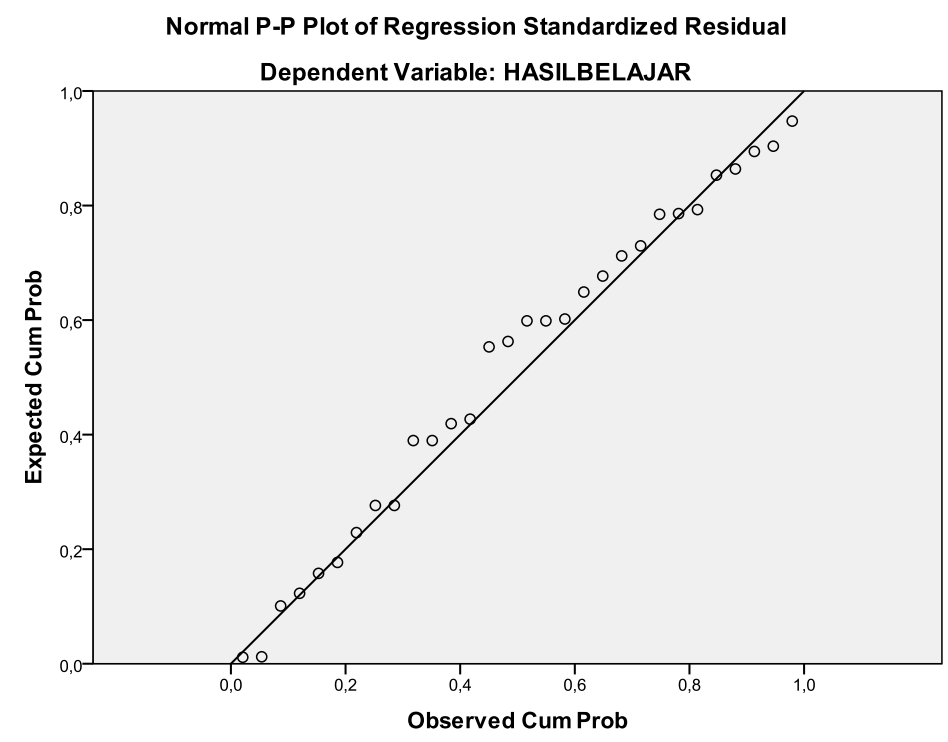

Gambar 2. Normal P-P Plot Regression Standardizer Residual

Data dikatakan normal apabila terdapat titik-titik yang menyebar tidak jauh dari gari diagonal, berdasarkan gambar 2. mengenai gambar p-p plot di atas terlihat bahwa titik-titik menyebar tidak jauh dari garis diagonal sehingga dapat dikatan data pada pengujian ini telah terdistribusi normal dan dapat dilanjutkan ke uji selanjutnya.

Table 2. Uji Analisis Regresi Sederhana

Coefficients $^{\mathrm{a}}$

\section{Table 2. Uji Analisis Regresi Sederhana}

\begin{tabular}{|c|c|c|c|c|c|c|}
\hline \multirow{2}{*}{\multicolumn{2}{|c|}{ Model }} & \multicolumn{2}{|c|}{ Unstandardized Coefficients } & $\begin{array}{l}\text { Standardized } \\
\text { Coefficients }\end{array}$ & \multirow[b]{2}{*}{$\mathrm{T}$} & \multirow[b]{2}{*}{ Sig. } \\
\hline & & $\mathrm{B}$ & Std. Error & Beta & & \\
\hline 1 & (Constant) & 25,226 & 7,750 & & 3,255 &, 003 \\
\hline a. Depe & $\begin{array}{l}\text { INTERAKTIF } \\
\text { ndent Variable: }\end{array}$ &, $\mathbf{6 2 8}$ &, 124 & ,692 & 5,075 & ,000 \\
\hline
\end{tabular}

$$
\begin{aligned}
& Y=a+b X \\
& Y=25,226+0,628 X
\end{aligned}
$$

Persamaan tersebut dapat diterjemahkan sebagai berikut:

Nilai konstanta sebesar 25,226artinya nilai konsisten variabel interaktif kelas yaitu sebesar 25,226. Mengandung arti bahwa ketika tidak terdapat pengaruh dari variabel bebas $\mathrm{X}$ (interaktif kelas) terhadap variabel terikat $\mathrm{Y}$ (hasil belajar) maka diperoleh nilai sebesar 25,226 satuan perpoin dari variabel interaktif kelas. 
Nilai koefisien regresi $X$ sebesar 0,628 menyatakan bahwa pada setiap penambahan $1 \%$ nilai trust, maka nilai interaksi kelas juga akan bertambah sebesar 0,628. Koefisien regresi nilainya positif, sehingga dapat dikatakan bahwa variabel interaktif kelas mempunyai arah pengaruh yang positif terhadap variabel hasil belajar.

Tabel 3. Uji Hipotesis

Coefficients $^{\mathrm{a}}$

\begin{tabular}{|c|c|c|c|c|c|c|}
\hline \multirow[b]{2}{*}{ Model } & & \multicolumn{2}{|c|}{ Unstandardized Coefficients } & \multirow{2}{*}{$\begin{array}{l}\text { Standardized } \\
\text { Coefficients } \\
\text { Beta }\end{array}$} & \multirow[b]{2}{*}{$\mathrm{T}$} & \multirow[b]{2}{*}{ Sig. } \\
\hline & & $\mathrm{B}$ & Std. Error & & & \\
\hline \multirow[t]{2}{*}{1} & (Constant) & 25,226 & 7,750 & & 3,255 & ,003 \\
\hline & INTERAKTIF & ,628 &, 124 & ,692 & 5,075 &, 000 \\
\hline
\end{tabular}

a. Dependent Variable: HASILBELAJAR

Pengujian Hipotesis Alternatif (Ha)

Adapun dasar pengambilan keputusan adalah sebagai berikut:

a. Jika nilai $\mathrm{Sig}<0,05$ atau $\mathrm{t}_{\text {hitung }}>\mathrm{t}$ tabel, maka terdapat pengaruh variabel $\mathrm{X}$ terhadap variabel $\mathrm{Y}$

b. Jika nilai Sig $>0,05$ atau $\mathrm{t}_{\text {hitung }}<\mathrm{t}_{\text {tabel }}$, maka tidak terdapat pengaruh variabel $\mathrm{X}$ terhadap variabel $\mathrm{Y}$

Adapun pengujian Hipotesis Alternatif (Ha) adalah sebagai berikut:

$t_{\text {tabel }}=t(\alpha / 1 ; n-k-1)=t(0,05 ; 28)=1,701$

Berdasarkan tabel 4.8 uji hipotesis di atas memperoleh nilai Sig. interaktif kelas (X) adalah sebesar $0,000<0.05$ maka dapat dikatakan bahwa terdapat pengaruh interaktif kelas terhadap hasil belajar warga belajar atau dengan kata lain nilai $\mathrm{t}$ Hitung 5,075> $\mathrm{t}$ tabel 1,701.Dengan demikian hipotesis pertama $\left(\mathrm{H}_{\mathrm{a}}\right)$ interaksi kelas dapat dibuktikan atau diterima.

Model Summary ${ }^{\mathrm{b}}$

Tabel 4. Uji Koefisien Determinasi

\begin{tabular}{|c|c|c|c|c|}
\hline Model & $\mathrm{R}$ & R S & $\begin{array}{l}\text { Adjusted } \\
\text { Square }\end{array}$ & $\begin{array}{l}\mathrm{R} \text { Std. Error of the } \\
\text { Estimate }\end{array}$ \\
\hline 1 &, $692^{\mathrm{a}}$ & ,479 & ,461 & 4,88010 \\
\hline
\end{tabular}

a. Predictors: (Constant), INTERAKTIF KELAS

b. Dependent Variable: HASILBELAJAR

Berdasarkan hasil uji koefisien determinasi yang terlihat pada tabel 4.9 di atas diperoleh nilai $\mathrm{R}$ sebesar 0,692 artinya terdapat pengaruh yang kuat variabel 
interaktif kelas terhadap variabel hasil belajar warga belajar. Nilai R Square sebesar 0,497 atau sebesar 49,7\% variabel interaktif kelas memberikan kontribusi untuk mempengaruhi variabel hasil belajar warga belajar. Adapun sisanya sebesar $50,3 \%$ di pengaruhi oleh faktor-faktor lain yang tidak di ikut sertakan dalam penelitian ini.

\section{Pembahasan}

Berdasarkan hasil penelitian interaktif kelas yang terlaksana di Sanggar Kegiatan Belajar (SKB) sudah baik, hal ini dapat dilihat berdasarkan jawaban penyebaran kuisioner interaktif kelas berada dalam kritera baik, indikator tertinggi pada variabel interaktif kelas yaitu pada indikator kelas interaktif pada pertanyaan ke 2 yaitu Dalam proses pembelajaran pamong menjelaskan dengan baik?hasil jawaban dapat menjelaskan bahwa pamong dalam proses pembelajaran dapat menjelaskan dengan baik hal ini akan meningkatkan hasil belajar warga belajar.

Hasil penyebaran kuisioner di Sanggar Kegiatan Belajar Kota Gorontalo hasil belajar warga belajar berada pada kriteria baik, jawaban indikator tertinggi pada variabel ini yaitu pada indikator ranah afektif yaitu pada pernyatan ke 2 yaitu saya bersikap baik terhadap pamong dalam proses pembelajaran dan pertanyaan ke 3 saya selalu memahami dengan baik pelajaran yang diberikan oleh pamong dapat di jelaskan bahwa warga belajar mengikuti proses pembelajaran dengan baik hal ini dapat meningkatkan hasil belajar warga belajar.

Indikator Pola-pola interaksi kelas, dalam kenyaataannya interaksi antara pamong dan warga belajar digambarkan sebagai bentuk komunikasi yang sangat terbatas, misalnya belajar untuk memberikan jawaban yang diharapkan terhadap pertanyaan-pertanyaan yang diberikan pamong bukan sebagai permintaan untuk memperoleh informasi, tetapi sebagai kesempatan untuk mengetahui penguasaan terhadap materi tersebut. Dengan indikator ini apabila pola interaksi pamong terhadap warga belajar baik maka berdampak baik pula pada hasil belajar warga belajar. Berdasarkan hasil penelitian di Sanggar Kegiatan Belajar Kota Gorontalo cara komunikasi pamong kepada warga belajar berjalan dengan baik, pamong sering bertanya kepada warga belajar mengenai pembelajaran,warga belajar dapat berperan aktiv dalam diskusi, pamong mengelompokan warga belajar dalam 
proses pembelajaran, pamong melakukan pertanyaan pelajaran minggu sebelumnya dengan pola-pola tersebut hasil belajar warga belajar baik.

Indikator kelas interaktif melibatkan para warga belajar dalam tugas-tugas bersama yang menuntut berbagai fungsi-fungsi bahasa yang berbeda (misalnya, menyarankan, meminta, mengarahkan, meminta, meyakinkan, memuji, menjelaskan, dan menginformasikan). Dengan indikator ini diharapkan dapat meningkatkan hasil belajar warga belajar, berdasarkan hasil penelitian melalui penyebaran kuisioner menghasilkan bahwa pamong selalu meminta warga belajar untuk menyelesaikan tugas tepat waktu, Penjelasan pamong saat belajar dapat dimengerti oleh warga belajar, pamong tidak memberikan perhatian lebih kepada warga belajar yang lebih aktif saja, aktivitas membaca dapat meningkatkan hasil belajar warga belajar dan diskusi dapat meningkatkan hasil belajar dapat dijelaskan bahwa interaksi kelas sudah terlaksana dengan baik hal ini dapat meningkatkan hasil belajar warga belajar di Sanggar Kegiatan Belajar Kota Gorontalo.

Indikator karakteristik berbasis interaksi menghasilkan jawaban dengan melalui penyebaran kuisioner yaitu semua warga belajar dapat memberikan kontribusi, semua warga belajardierikan kesempatan untuk berkomunikasi dan berpendapat, pamong selalu menggunkan aktivitas-aktivtas yang menarik, bermanfaat dan menantang bagi warga belajar, warga belajar terbiasa membahas permasalahan dan mencari solusi saat diskusi, keadilan pamong merata kepada warga belajar, hal ini dapat meningkan hasil belajar warga belajar menjadi baik.

\section{SIMPULAN}

Berdasarkan hasil penelitian dapat disimpulkan bahwa terdapat Pengaruh interaktif kelas terhadap hasil belajar warga belajar pada Program Paket B mata pelajaran Bahasa Indonesia. Pengaruhnya dapat dijelaskan sebagai berikut:

1. interaktif kelas $(\mathrm{X})$ adalah sebesar $0,000<0.05$ maka dapat dikatakan bahwa terdapat pengaruh interaktif kelas terhadap hasil belajar warga belajar atau dengan kata lain nilai $\mathrm{t}_{\text {Hitung }}$ 5,075> $\mathrm{t}$ tabel 1,701. Dengan demikian hipotesis pertama $\left(\mathrm{H}_{\mathrm{a}}\right)$ interaktif kelas dapat dibuktikan atau diterima. 
2. Indikator-indikator variabel interaktif kelas yang dapat mempengaruhi variabel hasil belajar yaitu indikator pola-pola interaksi kelas dan indikator interaksi kelas.

3. Nilai R Square sebesar 0,497 atau sebesar 49,7\% variabel interaktif kelas memberikan kontribusi untuk mempengaruhi variabel hasil belajar warga belajar. Adapun sisanya sebesar 50,3\% di pengaruhi oleh faktor-faktor lain yang tidak di ikut

\section{DAFTAR PUSTAKA}

Arif Abdul. 2020. Pengembangan Multemdia Interaktif Pada Mata Pelajaran Dasar Listrik dan Elektronika Kelas X Di SMK Muhammadiyah. JTEVJurnal Teknik Elektro San Vokasi1 Padang 06 (01) hall 144

Arsyad, Azhar. 2017. Media Pembelajaran. Jakarta: Raja Grafindo Persada.

Mulyana, Aina. 2018. Model Pembelajaran Interaktif. Tersedia di ainamulyana.blogspot.com/2012/02/model-pembelajaran-interaktif.html. diakses, 15 November 2020

Mulyasa. 2004. Menjadi Kepala Sekolah Profesional. Bandung, Rosda

Setyanigsih Sri. 2020. Pengaruh Penggunaan Media Pembelajaran Interaktif Berbasis Articulate Storyline Terhadap Motivas Belajar Dan Hasil Belajar Warga Belajar. Jurnal Pendidikan Dan Ilmu Pengetahuan. 20 (02) hall 145.

Sugiyono. (2014). Metode Penelitian Pendidikan Pendekatan Kuantitatif, Kualitatif, dan $R \& D$. Bandung: Alfabeta.

Sugiyono. 2012. Metode Penelitian Kuantitatif Kualitatif dan R\&D. Bandung: Alfabeta.

Prasetyo Iis. 2017. Peran Pamong Dalam Meningkatka Motivasi Warga Belajar Program Paket B. DIKLUS-Jurnal Pendidikan Luar Sekolah 06 (11) hall $45-46$ 